\title{
PERBANDINGAN KADAR LEUKOSIT DARAH PADA PASIEN APENDISITIS AKUT DAN APENDISITIS PERFORASI DI RSUD MEURAXA BANDA ACEH
}

\author{
Aya Sophia $^{1}$, M.Hendro Mustaqim², Fakhrul Rizal² \\ ${ }_{1}^{1}$ Mahasiswa Program Studi Pendidikan Dokter, Aceh, Indonesia \\ ${ }^{2}$ Dosen Program Studi Pendidikan Dokter, Aceh Besar, Indonesia
}

\begin{abstract}
Comparison of Blood Leukocyte Levels in Patients with Acute Appendicitis and Perforated Appendicitis at Meuraxa Hospital, Banda Aceh. Appendicitis is defined as inflammation of the appendix vermiformis (worm sac) which is the most common surgical emergency in children and young adults with abdominal pain. Appendicitis is thought to be caused by obstruction of the appendix lumen by faecalith, faecal stasis, lymphoid hyperplasia or caecal neoplasms and various infections by pathogens. This study aims to determine the comparison of blood leukocyte levels in acute appendicitis and perforated appendicitis in Meuraxa Hospital, Banda Aceh. This type of research is a retrospective study survey research with cross sectional research design. Retrieval of data from medical records. The number of samples used 89 people consisting of 56 patients with acute appendicitis and 33 patients with perforated appendicitis. Data analysis using Independent sample t-test. The mean value of blood leukocytes in patients with acute appendicitis was 10,741.8 cells/mm3 and perforated appendicitis was 20,023.6 cells $/ \mathrm{mm} 3$. The results of this study showed the $\mathrm{p}$-values of acute appendicitis and perforated appendicitis patients were $P=0.239$ and $P=0.749$, respectively. Independent test sample $t$ test obtained t test statistics of $-11,963$ with $P<0,001$. There is a difference between blood leukocyte levels in patients with acute appendicitis and perforated appendicitis.
\end{abstract}

Keywords:Acute appendicitis, perforated appendicitis, blood leukocytes.

\begin{abstract}
Abstrak: Perbandingan Kadar Leukosit Darah Pada Pasien Apendisitis Akut dan Apendisitis Perforasi Di RSUD Meuraxa Banda Aceh. Apendisitis didefinisikan sebagai peradangan pada apendiks vermiformis (kantong cacing) yang merupakan darurat bedah paling umum pada anak-anak dan dewasa muda dengan nyeri perut. Apendisitis diduga disebabkan oleh obstruksi lumen apendiks oleh faecalith, stasis faecal, hiperplasia limfoid atau caecal neoplasma dan berbagai infeksi oleh patogen. Penelitian ini bertujuan untuk mengetahui perbandingan kadar leukosit darah pada apendisitis akut dan apendisitis perforasi di RSUD Meuraxa Banda Aceh. Jenis penelitian ini adalah penelitian survei studi retrospektif dengan desain penelitian cross sectional. Pengambilan data dari catatan rekam medis. Jumlah sampel yang digunakan 89 orang yang terdiri dari 56 orang pasien apendisitis akut dan 33 orang pasien apendisitis perforasi. Analisis data menggunakan Uji T-test sampel tidak berpasangan (Independent sample $t$-test). Nilai rerata leukosit darah pada pasien apendisitis akut sebesar $10.741,8 \mathrm{sel} / \mathrm{mm}^{3}$ dan apendisitis perforasisebesar $20.023,6 \mathrm{sel} / \mathrm{mm}^{3}$. Hasil penelitian ini menunjukan nilai $p$-value pasien apendisitis akut dan apendisitis perforasi masing-masing adalah $\mathrm{P}=0,239$ dan $\mathrm{P}=0,749$. Uji Independent sample $t$ test diperoleh statistik uji $\mathrm{t}$ sebesar $-11,963$ dengan $\mathrm{P}<0,001$. Terdapat perbedaan antara kadar leukosit darah pada pasien apendisitis akut dan apendisitis perforasi.
\end{abstract}

Kata kunci: Apendisitis Akut, Apendisitis Perforasi, Leukosit darah. 


\section{PENDAHULUAN}

Apendisitis adalah penyebab paling umum dari nyeri perut akut yang dijumpai pada bagian departemen bedah (Biricik et al., 2019). Apendisitis didefinisikan sebagai peradangan pada apendiks vermiformis (kantong cacing) yang merupakan darurat bedah paling umum pada anak-anak dan dewasa muda dengan nyeri perut. Apendisitis diduga disebabkan oleh obstruksi lumen apendiks oleh faecalith, stasis faecal, hiperplasia limfoid atau caecal neoplasma dan berbagai infeksi oleh patogen (Guy \& Wysocki, 2018). Rentang usia yang paling umum terjadi antara 10-30 tahun (Sellars \& Boorman, 2017). Prevalensi apendisitis lebih tinggi pada usia 25 tahun (Kowalak et al., 2011). Risiko kejadian seumur hidup lebih tinggi pada pria dengan persentase $8,6 \%$ daripada wanita 6,7\% (Boardman \& Musisca, 2019).

Menurut World Health Organization (WHO) 2004 dalam data Global Burden Disease tercatat sebanyak 259 juta kasus apendisitis pada pria seluruh dunia yang tidak terdiagnosis, sementara pada wanita terdapat 160 juta kasus tidak terdiagnosis (The Global Burden Of Disease, 2004). Insiden apendisitis akut di negara maju terjadi sekitar 90-100 pasien per 100.000 penduduk per tahun. Berdasarkan letak geografis dilaporkan risiko seumur hidup apendisitis akut sebesar 9\% di Amerika Serikat, $8 \%$ di Eropa, dan $2 \%$ di Afrika. Insiden apendisitis akut lebih rendah pada orang dengan asupan makanan yang tinggi akan serat. Serat makanan diduga dapat mengurangi viskositas feses, mengurangi waktu transit usus, dan mencegah pembentukan faecalith yang dapat menyumbat lumen apendiks (Podda \& Cillara, 2018).

Apendisitis merupakan beban yang signifikan terhadap penanganan operasi umum darurat di Amerika Serikat (Dhillon et al., 2019). Prevalensi apendisitis seumur hidup diAmerika Serikat adalah 1 dari 15 . Tingkat prevalensi pada pria lebih tinggi dari wanita dengan rasio sekitar $1,4: 1$
(Biricik et al., 2019). Apendisitis akut adalah salah satu patologi yang paling sering menyerang manusia, dengan perkiraan $8 \%$ populasi dunia melakukan operasi untuk keadaan tersebut (Fortea-Sanchis et al., 2020). Kejadian apendisitis akut mengalami peningkatan setiap tahun dan sekarang mempengaruhi 9,4 per 10.000 orang, sehingga menghasilkan sekitar 30.000 kasus per tahun. Patogenesis apendisitis akut melibatkan peradangan awal dinding apendiks yang mengarah ke iskemia lokal, nekrosis, dan berisiko perforasi (Nimmagadda et al., 2019). Kejadian apendisitis perforasi bervariasi dari $16-40 \%$, dengan frekuensi lebih tinggi terjadi pada kelompok usia yang lebih muda (40-57\%) dan pada pasien usia $>50$ tahun (55-70\%) (Podda \& Cillara, 2018). Apendisitis perforasi dapat menyebabkan berbagai komplikasi (Tsai et al., 2017). Sepertiga dari kasus apendisitis yang dirujuk ke rumah sakit adalah apendisitis perforasi (Biricik et al., 2019). Tingkat kematian pada anakanak berkisar antara $0,1 \%$ hingga $1 \%$ (Podda \& Cillara, 2018).

Berdasarkan data Kementerian Kesehatan Republik Indonesia (Kemenkes RI) tahun 2012, apendisitis termasuk dalam peringkat 10 besar penyakit tidak menular penyebab rawat inap di rumah sakit tahun 2009 dan 2010 (Kemenkes RI, 2012). Penyakit tidak menular merupakan penyebab kematian hampir $70 \%$ didunia. Menurut hasil Riset Kesehatan Dasar (Riskesdas) tahun 2007, 2013, dan 2018 tampak kecenderungan peningkatan prevalensi penyakit tidak menular. Fenomena ini diprediksi akan terus berlanjut (Kemenkes RI, 2019). Berdasarkan hasil penelitian Gloria A.Thomas di RSUP Prof.Dr.R.D.Kandou Manado periode Oktober 2012-September 2015 angka kejadian apendisitis terdapat sebanyak $63 \%$ pasien terdiagnosis apendisitis akut dan $30 \%$ pasien terdiagnosis apendisitis perforasi (Thomas et al., 2016). Di Aceh, berdasarkan hasil penelitian Lestari (2015) di RSUD dr.Zainoel Abidin angka kejadian apendisitis akut pada pria 
sebanyak $51,7 \%$ dan wanita sebanyak $48,3 \%$. Kejadian apendisitis perforasi pada pria dan wanita sama yaitu $50 \%$ (Lestari, 2015).

Diagnosis apendisitis dapat ditegakkan berdasarkan temuan dari anamnesis, pemeriksaan fisik, pemeriksaan laboratorium, dan pemeriksaan penunjang (Matthew et al., 2018). Dalam mendiagnosis apendisitis akut secara akurat dan efisien dapat mengurangi morbiditas dan mortalitas akibat perforasi dan komplikasi lainnya seperti pembentukan abses, sepsis, dan adhesi intra-abdominal (Kabir et al., 2017). Banyak peneliti yang telah meneliti penggunaan biomarker untuk mendiagnosis dini apendisitis akut seperti kadar sel darah putih (leukosit) (Prasetya et al., 2019). Leukosit adalah unit yang dapat bergerak pada sistem pertahanan imun tubuh (Sherwood, 2014). Manfaat leukosit yang sesungguhnya ialah sebagian besar diangkut secara khusus ke daerah yang terinfeksi dan mengalami peradangan serius, dengan demikian menyediakan pertahanan yang cepat dan kuat terhadap agen-agen infeksius (Guyton \& Hall, 2016).

Pemeriksaan leukosit merupakan salah satu pemeriksaan laboratorium awal untuk mendeteksi apendisitis dengan ditandai adanya leukositosis. Hasil pemeriksaan menunjukkan $90 \%$ pasien apendisitis mengalami peningkatan leukosit antara 10.000 $\mathrm{sel} / \mu \mathrm{l}$ sampai dengan $15.000 \mathrm{sel} / \mu \mathrm{l}$. Leukosit melebihi $18.000-20.000 \mathrm{sel} / \mu \mathrm{l}$ menandakan kemungkinan terjadinya perforasi apendiks (Amalina, 2018). Mengetahui bahwa apendisitis merupakan penyakit tidak menular dan diperkirakan angka kejadian terus mengalami peningkatan. Penyakit tidak menular merupakan penyebab kematian hampir $70 \%$ didunia serta fenomena ini diprediksi akan terus berlanjut. Keterlambatan dalam mendiagnosis apendisitis akut dapat berakibat menjadi apendisitis perforasi yang dapat menimbulkan beberapa komplikasi seperti pembentukan abses, sepsis, dan adhesi intra-abdominal.
Keterlambatan mendiagnosis juga dapat meningkatkan morbiditas dan mortalitas. Berdasarkan pemaparan di atas, peneliti merasa tertarik untuk melakukan penelitian tentang perbandingan kadar leukosit darah pada pasien apendisitis akut dan apendisitis perforasi di RSUD Meuraxa Banda Aceh periode Januari-Desember 2019.

\section{METODE}

Jenis penelitian ini adalah penelitian survei studi retrospektif dengan desain penelitian cross sectional. Pengambilan data dari catatan rekam medis pasien apendisitis akut dan apendisitis perforasi di RSUD Meuraxa Banda Aceh periode JanuariDesember 2019.

Populasi pada penelitian ini adalah semua pasien yang terdiagnosis apendisitis akut dan apendisitis perforasi serta telah dilakukan pemeriksaan laboratorium darah di Bagian Bedah RSUD Meuraxa Banda Aceh periode Januari-Desember 2019. Penelitian ini menggunakan teknik pengambilan sampel non probability sampling, yaitu purposive sampling.

Instrumen yang digunakan dalam pengumpulan data penelitian ini adalah data sekunder dari catatan rekam medis hasil pemeriksaan laboratorium darah dan lembar penelitian.

Analisis data yang digunakan dalam penelitian ini analisis univariat dan analisis bivariat. Analisis univariat untuk mendeskripsikan karakteristik setiap variabel.Sedangkan analisis bivariat yang digunakan adalah Independent sample t-test.

\section{HASIL}

\section{Karakteristik pasien apendisitis akut dan perforasi}

Gambaran karakteristik dasar pasien apendisitis akut dan perforasi yang terlibat dalam penelitian ini dilihat berdasarkan variabel jenis kelamin dan kelompok usianya. Karakteristik pasien apendisitis akut dan perforasi berdasarkan kedua variabel tersebut disajikan pada Tabel 1. 
Tabel 1. Karakteristik pasien apendisitis akut dan perforasi

\begin{tabular}{ccc}
\hline \multirow{2}{*}{ Variabel } & \multicolumn{2}{c}{ Kelompok Pasien } \\
\cline { 2 - 3 } & Apendisitis AkutN (\%) & Apendisitis PerforasiN (\%) \\
\hline Jenis Kelamin & $25(44,6)$ & $20(60,6)$ \\
Laki-Laki & $31(55,6)$ & $13(39,4)$ \\
Perempuan & & \\
Kelompok Usia & $4(7,1)$ & $4(12,1)$ \\
$<11$ tahun & $13(23,2)$ & $8(24,2)$ \\
$11-20$ tahun & $21(37,5)$ & $7(21,2)$ \\
$21-30$ tahun & $10(17,9)$ & $6(18,2)$ \\
$31-40$ tahun & $8(14,3)$ & $8(24,2)$ \\
$>40$ tahun & &
\end{tabular}

Berdasarkan Tabel 1 , penelitian ini melibatkan 89 orang pasien apendisitis dengan perincian 56 orang $(69,2 \%)$ apendisitis akut dan 33 orang $(37,1 \%)$ apendisitis perforasi. Pasien dengan apendisitis akut lebih banyak yang berjenis kelamin perempuan yaitu sebanyak 31 orang $(55,6 \%)$. Pasien apendisitis perforasi lebih didominasi oleh pasien laki-laki dengan jumlah sebanyak 20 orang $(60,6 \%)$. Jika dilihat berdasarkan kelompok usianya, diketahui bahwa pasien apendisitis akut yang paling banyak berusia di antara 21 hingga 30 tahun yaitu sejumlah 21 orang $(37,5 \%)$. Sedangkan yang paling sedikit berada pada kelompok usia yang kurang dari 11 tahun yaitu hanya sebanyak 4 orang $(7,1 \%)$.

2. Gambaran kadar leukosit pada pasien apendisitis akut dan perforasi

Gambaran kadar leukosit pada pasien apendisitis akut dan perforasi dapat dilihat melalui beberapa nilai statistik di antaranya nilai rata-rata, median, minimum, maksimum dan standar deviasi (SD). Statistik deskriptif kadar leukosit pada pasien apendisitis akut dan perforasi ditampilkan pada Tabel 2.

Tabel 2. Statistik deskriptif kadar leukosit darah pada pasien apendisitis akut dan perforasi

\begin{tabular}{cccccc}
\hline Kelompok Pasien & Rata-Rata & Median & Minimum & Maksimum & SD \\
\hline Apendisitis Akut & $10.741,8$ & $10,350,0$ & $4.100,0$ & $18.000,0$ & $3.581,3$ \\
Apendisitis Perforasi & $20.023,6$ & $20.000,0$ & $12.600,0$ & $25.800,0$ & $3.455,7$ \\
\hline
\end{tabular}

Berdasarkan tabel di atas menunjukkan rata-rata jumlah leukosit pada pasien apendisitis perforasi adalah sebanyak 20.023,6 sel/ $\mathrm{mm}^{3}$ dan pada pasien apendisitis akut adalah sebanyak $10.741,8 \mathrm{sel} / \mathrm{mm}^{3}$. Nilai median yang menunjukkan nilai tengah data pada pasien apendisitis perforasi adalah sebesar $20.000,0 \mathrm{sel} / \mathrm{mm}^{3}$ dan pada pasien apendisitis akut sebesar $10.350,0 \mathrm{sel} / \mathrm{mm}^{3}$. Hal ini menunjukkan bahwa $50 \%$ pasien apendisitis perforasi memiliki jumlah leukosit di bawah
$20.000,0 \mathrm{sel} / \mathrm{mm}^{3}$ dan $50 \%$ lainnya memiliki jumlah leukosit di atas $20.000,0 \mathrm{sel} / \mathrm{mm}^{3}$. Pada pasien apendisitis akut, sebanyak $50 \%$ pasien memiliki jumlah leukosit di bawah $10.350,0 \mathrm{sel} / \mathrm{mm}^{3}$. Nilai standar deviasi jumlah leukosit pada kedua kelompok pasien tersebut tidak terlalu berbeda. Nilai SD yang besar menunjukkan bahwa data penelitian pada kedua kelompok cenderung lebih beragam (bervariasi). 
3. Perbandingan kadar leukosit darah pada pasien apendisitis akut dan perforasi

Tabel 3, menyajikan dua statistik penting dari uji Independent sample $t$ test, yaitu nilai statistik uji $t$ dan $p$ value pengujiannya. Perbandingan kadar leukosit pada kedua kelompok pasien menghasilkan statistik uji $t$ sebesar $-11,963$ dengan $p$-value pengujian yang jauh lebih kecil dari pada 0,001. Dengan demikian, dapat diputuskan bahwa kadar leukosit pada kedua kelompok pasien apendisitis adalah berbeda nyata pada tingkat signifikansi sebesar 0,05.

Tabel 3. Perbandingan kadar leukosit darah pada pasien apendisitis akut dan perforasi

\begin{tabular}{cccc}
\hline Kelompok Pasien & Statistik Uji $\boldsymbol{t}$ & $\boldsymbol{p}$-value & Kesimpulan \\
\hline $\begin{array}{c}\text { Apendisitis Akut } \\
\text { Apendisitis Perforasi }\end{array}$ & $-11,963$ & $<0,001$ & $\begin{array}{c}\text { Kadar leukosit pada kedua } \\
\text { kelompok apendisitis berbeda }\end{array}$ \\
\hline
\end{tabular}

\section{Tabulasi silang uji Pearson Chi-Square kejadian apendisitis akut dan perforasi berdasarkan jenis kelamin \\ Berdasarkan tabel 4, diketahui} bahwa nilai statistik Pearson Chi-square untuk hubungan antara variabel jenis kelamin dengan kejadian apendisitis akut dan perforasi adalah sebesar 2,117 dengan $p$-value sebesar 0,146 .
Oleh karena $p$-value pengujian berada di atas 0,05, maka dapat disimpulkan bahwa hipotesis nol penelitian tidak dapat ditolak. Dengan kata lain, tidak terdapat hubungan yang signifikan antara variabel jenis kelamin dengan kejadian apendisitis akut dan perforasi pada pasien di RSUD Meuraxa Banda Aceh.

Tabel 4. Tabulasi silang uji Pearson Chi-Square

\begin{tabular}{cccc}
\hline Statistik uji & Nilai & p-value & Kesimpulan \\
\hline Pearson Chi-Square & $2,117^{*}$ & 0,146 & $\begin{array}{c}\text { Variabel jenis kelamin tidak } \\
\text { berhubungan dengan kejadian } \\
\text { apendisitis }\end{array}$ \\
\hline
\end{tabular}

\section{PEMBAHASAN}

Menurut kelompok usia, pasien yang paling banyak menderita apendisitis akut adalah kelompok usia 21-30 tahun sebanyak 21 orang $(37,5 \%)$ dan apendisitis perforasi adalah kelompok usia $11-20$ tahun 8 orang $(24,2 \%)$. Hasil tersebut sesuai dengan literatur, rentang usia yang paling umum terjadi antara usia 10-30 tahun (Sellars \& Boorman, 2017). Hal ini sejalan dengan penelitian yang dilakukan Lestari (2015) di RSUD dr.Zainoel Abidin mengenai kelompok usia yang paling banyak menderita apendisitis adalah kelompok usia 11-20 tahun dan 21-30 tahun yaitu masing-masing sebanyak 16 orang $(26,7 \%)$ terutama apendisitis akut (Lestari, 2015). Distribusi usia pasien apendisitis di RSUP Sanglah Denpasar tahun 2015-2017 berdasarkan penelitian Cathleya Fransisca menunjukkan bahwa apendisitis terbanyak terdapat pada kelompok usia remaja akhir (17-25 tahun) yaitu sebanyak 212 orang $(29,3 \%)$ dan diikuti pada kelompok usia dewasa awal (26-35 tahun) yaitu sebanyak 132 orang $(18,3 \%)$ (Fransisca, 2019).

Kejadian apendisitis perforasi pada penelitian ini tersebar merata pada hampir semua kelompok umur. Jumlah pasien apendisitis perforasi yang paling banyak masing-masing 8 orang (24,2\%) pada kelompok usia (11-20 tahun) dan (>40 
tahun). Hal tersebut sejalan dengan penelitian di RSUP Prof.Dr.R.D.Kandou Manado, distribusi pasien apendisitis perforasi terbanyak pada kelompok usia 10-19 tahun sebanyak 69 orang (Thomas et al., 2016). The American Journal of Surgery menyebutkan bahwa pasien usia lanjut memiliki kemungkinan lima kali lebih tinggi untuk menderita apendisitis perforasi dibandingkan dengan pasien usia yang lebih muda. Penanganan pada pasien usia lanjut merupakan tantangan bagi ahli bedah (Dhillon et al., 2019).

Dari hasil penelitian menunjukkan bahwa pasien apendisitis akut lebih banyak berjenis kelamin perempuan yaitu 31 orang $(55,6 \%)$ dari pada laki-laki 25 orang $(44,6 \%)$ dan sebaliknya pada pasien apendisitis perforasi. Hasil penelitian ini tidak sejalan dengan literatur yang menunjukkan tingkat prevalensi pada laki-laki lebih tinggi dari wanita dengan rasio sekitar 1,4:1 (Biricik et al., 2019) Penelitian Windy C.S. menunjukkan hal yang serupa yaitu diperoleh insidensi tertinggi apendisitis akut didapatkan pada perempuan (66,6\%) (Windy, 2016). Berdasarkan uji statistik didapatkan jenis kelamin tidak memiliki hubungan signifikan dengan kejadian apendisitis akut dan apendisitis perforasi dengan nilai uji statistik Pearson Chi-Square sebesar 2,117 dan $p$-value sebesar 0,146. Hubungan tingginya kejadian apendisitis dengan jenis kelamin belum diketahui penyebab pasti karena bentuk apendiks laki-laki dan perempuan secara anatomi sama. Hal ini dapat terjadi karena pada perempuan sering ditemukan kasus apendisitis akut positif palsu sebanyak $20 \%$ pada rentang usia 20-40 tahun (Windy, 2016). Kejadian apendisitis perforasi lebih banyak terjadi pada laki-laki 20 orang $(60,6 \%)$ dari pada perempuan 13 orang $(39,4 \%)$. Hasil ini sejalan dengan penelitian (Bagus, 2020) sebanyak 27 orang $(45,8 \%)$ mengalami apendisitis perforasi berjenis kelamin laki-laki dan perempuan sebanyak 6 orang $(16,2 \%)$ (Bagus, 2020).

Hasil analisis dengan uji Independent sample $t$ test diperoleh statistik uji $t$ sebesar -11,963 dengan $p$-value $<0,001$. Oleh karena itu, dapat disimpulkan kadar leukosit pada kedua kelompok apendisitis berbeda. Hasil penelitian ini sesuai dengan penelitian di RSUP dr. Kariadi Semarang diperoleh nilai $p$-value $<0,001$ dan di RSUD dr.Zainoel Abidin didapatkan nilai $p$-value $=0,000$, hal ini berarti terdapat perbedaan jumlah leukosit pada pasien apendisitis akut dan apendisitis perforas (Lestari, 2015; Sibuea, 2014).

\section{KESIMPULAN}

Berdasarkan hasil penelitian dapat disimpulkan bahwa terdapat perbedaan antara kadar leukosit darah pada pasien apendisitis akut dan apendisitis perforasi di RSUD Meuraxa Banda Aceh. Rerata kadar leukosit darah pada pasien apendisitis akut sebesar $10.741,8 \mathrm{sel} / \mathrm{mm}^{3}$ dan apendisitis perforasisebesar 20.023,6 $\mathrm{sel} / \mathrm{mm}^{3}$.Kelompok usia yang paling banyak menderita apendisitis akut adalah kelompok usia 21-30 tahun dan apendisitis perforasi tersebar merata pada seluruh kelompok usia.Jenis kelamin tidak berhubungan terhadap kejadian apendisitis akut dan apendisitis perforasi.

\section{SARAN}

Berdasarkan penelitian yang telah dilakukan berikut beberapa saran untuk selanjutnya:

1. Penelitian selanjutnya diharapkan jumlah sampel penelitian lebih besar atau range tahun yang diambil lebih lama agar dapat melihat perbedaan yang lebih bermakna terkait dengan kadar leukosit darah pada pasien apendisitis akut dan apendisitis perforasi.

2. Bagi klinisi dan pihak rekam medik rumah sakit memperbaiki sistem pencatatan dan penyimpanan rekam medik pasien sehingga seluruh data yang dibutuhkan oleh peneliti tersedia.

\section{DAFTAR PUSTAKA}

Amalina, A. (2018). Hubungan Jumlah Leukosit Pre Operasi dengan Kejadian Komplikasi Pasca Operasi Apendektomi pada Pasien 
Apendisitis Perforasi di RSUP Dr. M. Djamil Padang. Jurnal Kesehatan Andalas, 7(4):491497.

Bagus, C. (2020). Gambaran Prediktor Perforasi pada Penderita Apendisitis di Rumah Sakit Umum Ari Canti Gianyar, Bali, Indonesia Tahun 2018. 11(1):122-128. https://doi.org/10.15562/ism.v11 i1.57

Biricik, S., Narcl, H., Dündar, G. A., Ayrık, C., \& Türkmenoğlu, M. Ö. (2019). Mean Platelet Volume and The Ratio of Mean Platelet Volume to Platelet Count in the Diagnosis of Acute Appendicitis. American Journal of Emergency Medicine, 37(3):411-414.

https://doi.org/10.1016/j.ajem.20 18.05.075

Boardman, T. J. \& Musisca, N. J. (2019). Recurrent Appendicitis Caused by a Retained Appendiceal Tip: A Case Report. Journal of Emergency Medicine, 57(2):232234.

https://doi.org/10.1016/j.jemerm ed.2019.03.044

Buletin Penyakit Tidak Menular. (2012). Kementerian Kesehatan RI.

Dhillon, N. K., Barmparas, G., Lin, T. L., Alban, R. F., Melo, N., Yang, A. R., Margulies, D. R., \& Ley, E. J. (2019). Unexpected Complicated Appendicitis in the Elderly Diagnosed with Acute Appendicitis. American Journal of Surgery, 218(6):1219-1222. https://doi.org/10.1016/j.amjsurg .2019 .08 .013

Fortea-Sanchis, C., Escrig-Sos, J., \& Forcadell-Comes, E. (2020). Diagnostic Yield of Abdominal Ultrasonography for the Diagnosis of Acute Appendicitis: A Global and Subgroup Analysis. Revista de Gastroenterología de México (English Edition), 85(1):12-17. https://doi.org/10.1016/j.rgmxen .2018 .11 .005

Fransisca, C. (2019). Karakteristik Pasien dengan Gambaran Histopatologi Apendisitis di RSUP Sanglah Denpasar Tahun 2015-
2017. Jurnal Medika Udayana, $8(7)$.

Guy, S., \& Wysocki, P. (2018). Risk Factors for Intra-Abdominal Abscess Post Laparoscopic Appendicectomy for Gangrenous or Perforated Appendicitis: A Retrospective Cohort Study. International Journal of Surgery Open, 10: 47-54. https://doi.org/10.1016/j.ijso.201 7.12.003

Guyton, A. C. \& Hall, J. E. (2016). Buku Ajar Fisiologi Kedokteran (E. I, I. Ilyas, M. D. Widjajakusumah, \& A. Tanzil (Eds.); Edisi Revisi). Elsevier Ltd.

Kabir, S. A., Kabir, S. I., Sun, R., Jafferbhoy, S., \& Karim, A. (2017). How to Diagnose an Acutely Inflamed Appendix: A Systematic Review of the Latest Evidence. International Journal of Surgery, 40:155-162. https://doi.org/10.1016/j.ijsu.201 7.03.013

Kowalak, J. P., Welsh, W., \& Mayer, B. (2011). Buku Ajar Patofisiologi (R. Komalasari (Ed.)). EGC.

Lestari, G. P. (2015). Perbedaan Jumlah Leukosit pada Pasien Apendisitis Akut dengan Apendisitis Perforasi yang Telah dioperasi di RSUD dr.Zainoel Abidin.

Matthew J. Snyder, Marjorie Guthrie, \& Staphem Cagle. (2018). Acute Appendicitis: Efficient Diagnosis and Management. American Family Physician, 98(1):25-33. https://www.aafp.org/afp/2018/0 701/p25.html

Nimmagadda, N., Matsushima, K., Piccinini, A., Park, C., Strumwasser, A., Lam, L., Inaba, K., \& Demetriades, D. (2019). Complicated Appendicitis: Immediate Operation or Trial of Nonoperative Management? American Journal of Surgery, 217(4):713-717.

https://doi.org/10.1016/j.amjsurg .2018.12.061

Podda, M., \& Cillara, N. (2018). Appendicitis. Encyclopedia of 
Gastroenterology (2nd ed., pp. 104-109). Elsevier. https://doi.org/10.1016/B978-012-801238-3.66055-5

Prasetya, D., Rochadi, \& Gunadi. (2019). Accuracy of Neutrophil Lymphocyte Ratio for Diagnosis of Acute Appendicitis in Children: A Diagnostic Study. Annals of Medicine and Surgery, 48(1):3538.

https://doi.org/10.1016/j.amsu.2 019.10 .013

Profil Kesehatan Indonesia 2018. (2019). Kementerian Kesehatan RI.

Sellars, H., \& Boorman, P. (2017). Acute Appendicitis. Surgery (United Kingdom), 35(8):432438. https://doi.org/10.1016/j.mpsur.2 017.06.002

Sherwood, L. (2014). Fisiologi Manusia Dari Sel ke Sistem (Edisi 8). EGC.

Sibuea, S. H. (2014). Perbedaan Antara Jumlah Leukosit Darah Pada Pasien Apendisitis Akut dengan Apendisitis Perforasi di RSUP DR.

Tsai, H. Y., Chao, H. C., \& Yu, W. J. (2017). Early Appendectomy Shortens Antibiotic Course and Hospital Stay in Children with Early Perforated Appendicitis. Pediatrics and Neonatology, 58(5):406-414. https://doi.org/10.1016/j.pedneo. 2016.09.001
Kariadi Semarang. Jurnal Media Medika Muda.

The Global Burden Of Disease. (2004). World Health Organization.

Thomas, G. A., Lahunduitan, I., \& Tangkilisan, A. (2016). Angka Kejadian Apendisitis Di RSUP Prof. Dr. R. D. Kandou Manado Periode Oktober 2012-September 2015. E-CliniC,4(1). https://doi.org/10.35790/ecl.4.1.

Windy, C.S. (2016). Perbandingan Antara Suhu Tubuh, Kadar Leukosit, dan Platelet Distribution Width (PDW) Pada Apendisitis Akut dan Perforasi. Jurnal Kesehatan Tadulako, 2(2):24-32. 